Politeness STRATEGies

IN UGANDAN ENGLISH:

MAKING REQUESTS

AND RESPONDING TO THANKS
Brno Studies in English

Volume 47, No. 1, 2021

ISSN 0524-6881 | e-ISSN 1805-0867 https://doi.org/10.5817/BSE2021-1-2

\title{
BEBWA ISINGOMA
}

\begin{abstract}
This study examines politeness strategies and specific expressions employed by Ugandans when making requests and responding to thanks, against the backdrop that contact phenomena, as one of the key factors that characterize L2 varieties such as Ugandan English, make it virtually inevitable to have peculiarities in this respect. Specifically, in relation to the illocutionary acts of request, Ugandan English relies more on direct strategies (due to substrate influence), with various idiosyncratic mitigating devices such as the use of the past progressive with performative verbs, the use of the lexical mitigator first with imperatives, and the use of verbs with inherent supplicatory semantics in the imperative mood. As regards responses to thanks, while there is a clear preference for exonormative standards, formulae arising from substrate influence are visibly present, while several of the formulae used in L1 English (e.g. Standard British English) are not used in Ugandan English.
\end{abstract}

Key words

Requests; responses to thanks; modality; direct strategies; exonormativity; Uganda

\section{Introduction}

From a linguistic perspective, politeness can be looked at in terms of respectful verbal acts meant to avoid conflicts in a given community of practice. Linguistic politeness involving both L1 English varieties (e.g. Brown and Levinson 1987, Schneider 2005, Bieswanger 2015) as well as L2 English varieties (e.g. Anderson 2009, Ouafeu 2009, Anchimbe 2019) has been investigated. Linguistic politeness manifests itself in various speech acts, notably apologies, requests, greetings, thanking, offers, offer refusals, complaints, etc. The current study looks at the linguistic strategies employed in Ugandan English to show politeness with respect to making requests and responding to thanks. Ugandan English is an L2 variety of English spoken in a former British protectorate, where there was no British settler community in the sense of Schneider $(2003,2007)$. This means that, during the protectorate time, Ugandans were not fully exposed to informal British 


\section{Bebwa Isingoma}

English (Meierkord 2016c). Ugandans have, thus, mainly acquired English in formal settings in schools and universities.

As far as linguistic politeness in Uganda is concerned, Lwanga-Lumu broke new ground in her 1999 article, where she considered L2 speakers of English whose mother tongue is Luganda - one of the indigenous languages spoken in Uganda. Ever since, she has conducted a couple of other studies along these lines. The topic only received attention from a variationist perspective when Meierkord (2016a) investigated "speech acts in Ugandan English social letters" and did not restrict herself to L1 Luganda speakers.

As is well known, many studies on politeness have been associated with the theory of face, following Goffman (1967) and Brown and Levinson (1978, 1987), whereby acts that run contrary to the face wants of an individual are dubbed as face-threatening acts (FTAs), e.g. orders, refusals and advice. A speaker is therefore supposed to use strategies that make FTAs (i.e. the imposition on the interlocutor) more polite. Given that the face theory does not place emphasis on cultural variations, which have been shown to be crucial in the realization of speech acts (cf. Lwanga-Lumu 1999), other theories that take care of them have thus emerged; among them is postcolonial pragmatics (Anchimbe and Janney 2011), which takes into account hybridic discourses resulting from the mixture of different sociocultural and linguistic elements as a corollary of colonization. Postcolonial pragmatics recognizes the fact that many Outer Circle Englishes have substantial substrate influence from indigenous languages, a need that arises from the fact that certain socio-cultural practices have to be preserved and expressed in the variety of English spoken in postcolonial territories. A related framework to postcolonial pragmatics in terms of recognizing regional and social variation as well as micro-social variables in the use of language in context is variational pragmatics (Barron and Schneider 2009). The theory combines pragmatics and variational sociolinguistics and is seen as "the study of intralingual macrosocial pragmatic variation" (Barron 2014: 1) that deals with how speakers of a given variety, say of English, realize speech acts involving linguistic actions such as requests, apologies, offers, appreciation, etc. in a given context. Schröder and Schneider (2018) express concern that it has not yet been widely used in comparing L1 Englishes with L2 Englishes. The few studies where it has been referred to include Farenkia (2013) and Schröder and Schneider (2018). As such, the mixture that postcolonial pragmatics underscores and both the macro-social and micro-social variables that variational pragmatics considers as cross-varietal factors in language use and variation underlie how Ugandans make requests and respond to thanks in English. We therefore expect divergences from L1 Englishes and from other L2 Englishes as well as interspeaker variability.

As is the case of many studies on requests (cf. Meierkord 2016a), the current study follows the widely used categories of strategies speakers use to make requests, proposed by Blum-Kulka and Olshtain (1984) and Blum-Kulka et al. (1989) in their CCSARP ${ }^{1}$ coding, which was aimed at comparing speech acts across cultures. Three broad categories have been proposed: (i) the most direct and explicit request strategies (where a request is syntactically realized by means of imperatives, explicit performatives or hedged performatives), (ii) the conven- 
tionally indirect strategies (using indirect speech acts, where suggestory formulae and reference to preparatory conditions are used) and (iii) the non-conventionally indirect strategies (where reference to an utterance makes the request be pragmatically implied, i.e. strong hint, and where the context provides room for interpreting the speech act as a request, i.e. mild hint). For example, while Go home is the most direct strategy as there is the use of the imperative, I'm a Moslem (in response to a friend's invite to go for pork) is the most indirect strategy (for examples of other scales, see e.g. Blum-Kulka and Olshtain 1984 and Blum-Kulka et al.1989). The taxonomy above provides for the fact that speakers employ various linguistic devices that either emphasize or mitigate the illocutionary force of a request, i.e. downgraders (e.g. please) and upgraders (e.g. the expletive bloody). These devices are either lexical (as in the above examples) or syntactic (e.g. the use of tense and aspect in I was wondering...). Co-occurrence of the lexical and syntactic devices is possible (e.g. I was wondering if you could please open the door).

Studies on responses to thanks (e.g. Aijmer 1996, Schneider 2005, Farenkia 2013, Bieswanger 2015) have identified five strategies with various response types that thankees use to respond to thanks: (i) minimizing the favor (e.g. the use of no problem, don't mention it, don't worry about it, okay); (ii) expressing pleasure (e.g. the expressions my pleasure, it's a pleasure); (iii) expressing appreciation of the addressee (e.g. using you are welcome, anytime); (iv) returning thanks (e.g. using the response thank you too) and (v) acknowledging the thanks (e.g. the use of yeah). The study at hand will adopt this widely used taxonomy to tease out the strategies and specific expressions that Ugandans use and to what extent they use them, as well as identifying specific expressions that stem from substrate influence since Ugandan English is an L2 variety.

The rest of this paper is organized as follows: Section 2 deals with what has been studied so far as regards requests and responses to thanks in African Englishes, including Ugandan English so as to establish to what extent indigenous socio-cultural linguistic norms have influenced how speakers of these Englishes make requests and respond to thanks. This section is followed by details about the methodology used in the study to collect the data (Section 3), which, in turn, is followed by the section on results and discussion, i.e. Section 4 . The paper finishes with concluding remarks in Section 5.

\section{Requests and responses to thanks in African Englishes}

While there are few studies that have dealt with the pragmatics of African Englishes (cf. Meierkord 2016a), those that have dealt with it have shown that it is usually shaped by features transferred from indigenous languages (Lwanga-Lumu 1999, Kasanga, 2006, Anderson 2009, Ouafeu 2009, Meierkord 2016a, Anchimbe 2019). A common characteristic of the African Englishes hitherto studied is that, as far as the illocutionary act of requests is concerned, they display the propensity of not using indirect strategies, which are, by contrast, preferred in L1 Englishes. Relevantly, Lwanga-Lumu (1999) and Blum-Kulka (1987) have shown that in some 


\section{Bebwa Isingoma}

societies (i.e. Luganda and Hebrew speech communities, respectively) indirectness is not necessarily a marker of politeness. For example, in Black South African English (Kasanga 2006), explicit performatives are the mostly used strategy when making polite requests. This, according to Kasanga (2006: 75), arises from the fact that "performatives and other requests with the form of 'direct requests' are commonly used in African languages to express 'positive politeness' or deference", as revealed by Gough (1995) and Lwanga-Lumu (1999). For example, in Northern Sotho (one of the indigenous languages spoken in South Africa), an utterance with an explicit performative verb such as (1) is regarded as a polite way of making a request: ${ }^{2}$

(1) Mohlomphegi, ke kgopela stapler. NORTHERN SOTHO (Kasanga 2006: 72) Sir/My lord I ask.PRES stapler.

'Sir, I am asking for a stapler.'

As can be seen, Kasanga (2006) explains that the illocutionary force embedded in the explicit performatives in such requests is usually mitigated by the use of downgraders, in the above case, the equivalent of the lexical item sir or lord. In a similar vein, Meierkord (2016a) reports on the use of explicit performatives as one of the preferred strategies in Ugandan English social letters, where an utterance like (2) is seen as a polite way of making a request. Indeed, this is not surprising in line with Kasanga's (2006) revelation about substrate influence. In Ugandan indigenous languages, such a polite request is realized in Rutooro as in (3) and in Acholi as in (4):

(2) I request you to send me money.

UGANDAN ENGLISH

(3) Ninkusaba ontwekere sente.

RUTOORO (BANTU)

Ni-n-ku-sab-a

o-n-twek-er-e

sente

PROG-I-you-request-FV you-me-send-APPL-FV

money

'I am requesting you to send me money.'

(4) Atye kalegi ni icwala cente.

A-tye ka-leg-i ni i-cwal-a cente

I-am PROG-request-you so that you-send-me money

'I am requesting you to send me money.'

In Rutooro and Acholi, not using mitigators with explicit performatives does not render the request impolite, although, as will be seen in Section 4, using them would make the request more polite. Hence, in (3) and (4) above, politeness is encoded by the semantics of the explicit performative verbs kusaba and leg 'ask/ request', respectively, which means that by using these verbs in the two languages, not only are the speakers performing the illocutionary act of request, but they are also doing so politely.

While Kasanga (2006) has demonstrated that the use of explicit performatives in making polite requests in Black South African English is the most preferred 
strategy, the most preferred strategy in Ugandan English, according to Meierkord (2016a: 243), is the use of mood derivables (with $63.0 \%$ as opposed to $11.5 \%$ for explicit performatives). On the other hand, in Ghanaian English, Anderson (2009) shows that the most preferred strategy is Want statements, followed by imperatives (mood derivables). All the strategies above may attract the use of mitigators in the varieties of English under consideration. Observably, all the L2 varieties share one thing, i.e. the preference of direct strategies (cf. Meierkord 2016a). However, they clearly differ as regards which type of direct strategy is preferred by a given variety, as shown above. Moreover, while there is the ubiquitous and peculiar use of mitigators with the direct strategies such as please (Anderson 2009, Lwanga-Lumu 1999), the current study has established that Ugandan English employs a number of mitigators not used in other African Englishes (as far as I can tell), which are, discernibly, not mentioned in Meierkord (2016a), as will be shown in Section 4.

Crucially, a direct corollary of the reliance on direct strategies by African Englishes is the usually infrequent use of indirect strategies as well as the use of modals and other concomitant syntactic mitigators, albeit at varying degrees for the different African Englishes. Such an infrequent use has been reported in Ghanaian English (Anderson 2009) and Kenyan English (Buregeya 2004). While Meierkord (2016a) observes that Ugandan English uses relatively more of the indirect strategies than Kenyan English (due to strong exonormative orientation in Uganda), it remains to be seen how micro-social situational parameters such as interlocutor status affect this sporadic use of indirect strategies. The current study will take this into account. As pointed out above, the role of exonormativity in shaping aspects of Ugandan English is crucial. This makes us predict some level of convergence with L1 Englishes especially standard British English. Exonormativity in Uganda has partly been associated with the fact that there were no significant numbers of English settlers in the sense of Schneider (2007) and this had the implication that Ugandans were not exposed to informal English nor non-standard/regional English spoken by uneducated British settlers (Meierkord 2016c). Thus, while substrate influence, with its underlying socio-cultural idiosyncrasies, has a role to play in the way Ugandans realize speech acts, there is also a competing force of exonormativity that comes into play, thereby making Ugandans display on the one hand patterns that conform to the British English norms and on the other hand hybridic patterns in which the role of their L1s is paramount.

Compared to the speech act of requests, the speech act of responding to thanks has received far less attention in African Englishes. As far as I can tell, only two African varieties of English have been analyzed, namely Cameroon English (Ouafeu 2009, Farenkia 2013) and Namibian English (Schröder and Schneider 2018). What is interesting in the above studies is two-fold: first, the above African varieties of English display features that markedly differ from L1 Englishes. Second, in terms of response strategies, African Englishes display varietal differences, thereby underscoring idiosyncrasies that set each national variety apart. Notably, while the most preferred strategy in Namibian English is expressing pleasure (Schröder and Schneider 2018), according to Ouafeu (2009), Cameroonians mainly use the 


\section{Bebwa Isingoma}

strategy of acknowledging the thanks (by saying yes). However, Farenkia (2013) gives us different results as regards the strategy that Cameroonians prefer, i.e. expressing appreciation of the addressee (using welcome and its variants). The discrepancies above between the two studies on Cameroon English could be attributed to the methods used to collect data: while Ouafeu used naturally occurring data, Farenkia used DCTs (see Section 3 for a discussion on the two methods). Nevertheless, what we discern from Schröder and Schneider (2018) and Ouafeu (2009) is the fact that the preferred strategies are shaped by indigenous languages (Ouafeu 2009) or exogenous languages, i.e. the role of Afrikaans in influencing Namibian English in this respect (Schröder and Schneider 2018), while from Farenkia (2013), we see the role of exonormativity at work.

There are no studies, to my knowledge, that have analyzed responses to thanks in Ugandan English. Nevertheless, the fact that we have seen two important forces that have shaped African Englishes in this respect (i.e. substrate influence and exonormativity), we expect these to have a role in the way Ugandans respond to thanks in English. It might, therefore, be rewarding to briefly look at how responses to thanks are realized in some Ugandan indigenous languages with a view to highlighting potential substrate influence, as is the case with Ouafeu's (2009) findings in relation to Cameroon English. From naturally occurring discourse, Kamoga and Stevick (1968: 161) provide the response kale 'all right/OK' in Luganda (Bantu) as well as the exclamation $\mathrm{mmm}$. These two responses belong to the strategy of minimizing the favor and acknowledging the thanks, respectively. From my personal insights as well as from consultations from native speakers of other Ugandan indigenous languages, kale 'all right/OK' also occurs in Rutooro, while its equivalents in Lugbara (Central Sudanic) and Acholi (Nilotic) are muke/ala and ber, respectively. The exclamation $\mathrm{mmm}$ can also be heard in the above languages, although it is considered less polite. In addition, minimizing the favor is also realized with the expressions si nnyo (Luganda), tikuli muno (Rutooro) and pee tutwal (Acholi), all of which can literally be rendered as 'not much/not all that'. Another strategy used in Ugandan indigenous languages is reciprocated thanks, as shown in the following table:

\begin{tabular}{|l|l|l|}
\hline Language & thanks & responses \\
\hline Rutooro & Webale & Naiwe webale ‘and you too, thank you' \\
\hline Acholi & Apwoyo & An bene apwoyo ‘me also, I thank you' \\
\hline Lugbara & Awadifo & Mi ni indi ‘also for you too' \\
\hline Luganda & Neeyanzizza & Nange neeyanzizza 'I also thank you'. \\
\hline
\end{tabular}

Table 1. Reciprocated thanks in some Ugandan languages

Reciprocated thanks in the above languages is seen as the most polite response whether the thanker has also done something for the thankee or not. 


\section{Methodology and data}

The study uses a mixed-method approach, namely corpus data, an elicitation test, a discourse completion task (DCT) (Blum-Kulka et al. 1989) and naturally occurring conversations (see below for details, as well as the motivation behind the mixed-method approach).

The participants came from different L1 backgrounds, in the main, Acholi, Luganda, Rutooro and Lugbara. Luganda and Rutooro are Bantu languages, the largest of the language subphyla in Uganda (64.8\%), while Acholi is one of the Nilotic languages, the second largest group (28.2\%) and Lugbara belongs to the central Sudanic languages, which constitute 6.8\% (cf. Namyalo et al. 2016: 27, Eberhard et al. 2019). While the purpose of this study is not to tease out variations stemming from the different L1s, it was necessary to have different L1 speakers so as to have a representative multilingual population, as Uganda is a multiethnic society. Crucially, the assumption that Ugandan English is mainly influenced by Luganda, the language spoken in the capital city of Uganda (cf. Fisher 2000, Isingoma 2013), has been proved to be incorrect (Isingoma 2014, Ssempuuma et al. 2016, Meierkord 2016b, Isingoma 2016a). Specifically, Isingoma (2014, 2016a) shows that Ugandan indigenous languages synergistically influence Ugandan English if the features displayed by the variety are shared by the Ugandan indigenous languages. On the other hand, if the features are not shared, then speakers of individual L1s will display heterogeneous features in their English(es) (cf. Ssempuuma et al. 2016, Meierkord 2016b). As mentioned above, for the current purposes, only homogeneous features are considered, while inter-speaker variations stemming from differences between indigenous languages (if any) would be a subject of future research.

In total, 80 participants were involved in the study, i.e. 40 in the elicitation test and the DCT, and 40 in the naturally occurring conversations. Both males and females were involved, although this was not considered as a predictor variable. While the participants in the DCT were mainly young adults, for they were university undergraduate students in 2019 , those in the naturally occurring conversations were a mixed category ranging from young adults to middle-age adults. Age was only considered with respect to the fact that the participants had to be adults who had completed at least secondary education in line with the criteria set for the collection of the ICE data (cf. Greenbaum and Nelson 1996). It was not considered here in terms of expecting different politeness strategies, since the scope of this component of the study (i.e. responses to thanks) did not consider micro-social variables. Given that this is the first analysis of responses to thanks in Ugandan English, the study is primarily meant to analyze strategies used by Ugandans in general. Fine details will be the subject of a different study (but see below for a different position as regards the component of the illocutionary act of requests).

For the data on requests, I made use of two datasets, i.e. corpus data and an elicitation test. The corpus data was obtained from the written component of the ICE-Uganda (see Isingoma and Meierkord 2019 for details) and spoken data (54,000 words). The spoken data, which is part of a relatively larger project for 


\section{Bebwa Isingoma}

the spoken component of the ICE-Uganda, was collected in 2018 by means of semi-structured conversations which were recorded. The same criteria used for the written component of the ICE-Uganda (cf. Isingoma and Meierkord 2019) were used. The data was transcribed and saved as plain-text files. The corpus data was used to search for indirect strategies where modals and other syntactic downgraders are used in the speech acts of requests. The data was searched using the AntConc concordancer software (Anthony 2004), by entering specific construction types involving modals and other syntactic downgraders (see Section 4). Where there was a need to vary certain constituents (e.g. pronouns), this was done during the search. After retrieving all the sentences containing the elements under consideration, the sentences were sorted manually to weed out those that did not involve requests (e.g. I was wondering if I did ever take...). Since this component of the study needed to include the interlocutors' status in order to find out circumstances under which the infrequently used indirect strategies for making requests occur in Ugandan English, the spoken data partly served this purpose as it comprised semi-structured conversations only. On the other hand, while Meierkord (2016a) looked at direct strategies in Ugandan English, she did not look at some idiosyncratic mitigators in this L2 variety. Given the limitations of the spoken data above (because of its size), or even the written component of the ICE-Uganda (also because of its size and limited text genres) (cf. Isingoma and Meierkord 2019), there was a need to obtain data that reflects the idiosyncratic mitigators under consideration, which I had already captured in my daily observations; thus, I used an elicitation test to this effect. Moreover, the elicitation test also served to corroborate the perceived unpopularity of indirect strategy constructions in Ugandan English, already observed in the corpus data. Besides, I needed to find out whether the non-occurrence in Ugandan English of a specific syntactic downgrader used in L1 English was due to what Ugandans may perceive as a grammatically incongruous construction (see Question 4, Appendix 1). The elicitation test had two types of questions with four questions in total (see Appendix 1): Questions 1 to 3 required the respondents to select the most appropriate alternatives they would use in order to make requests under given circumstances. The respondents were also asked to give reasons for their choices and for not choosing the other alternatives. Question 4, on the other hand, required the respondents to state whether the statement provided was grammatical or not, and to give reasons for their choices.

To obtain data on responses to thanks, I used the DCT and my ethnographic notebook of naturally occurring data. The DCT required the participants to write what they would say if their interlocutors told them 'thank you' after they had helped show them the way (Appendix 2). For the naturally occurring conversations, I would take down notes of replies made by my interlocutors whenever I thanked them for doing something for me. This was either face-to-face or by telephone. I did this for one month until I reached my target. As noted by Bieswanger (2015), there have been discrepancies between results obtained from naturally occurring data and DCTs, a situation that had been acknowledged by Schneider (2005), who had called for triangulating DCTs with other methods. The two methods were meant to complement each other, i.e. while the DCT 
gave the participants time to think and come up with what they felt was the most appropriate expression, the conversations permitted the study to have naturally occurring data that depicts spontaneous and instantaneous linguistic practices on the ground (see also Kasanga 2006).

\section{Requests and responses to thanks in Ugandan English}

\subsection{Requests}

That indirect strategies are not very common in African Englishes, Ugandan English inclusive, is an undisputed fact (Anderson 2009, Buregeya 2004, Kasanga 2006, Meierkord 2016a). For example, the following formulae (5) in italics (cf. Swan 2005: 409 and passim) are completely missing in the ICE-Uganda and the spoken data:

\section{L1 ENGLISH}

(5) (a) I was wondering if you could send me some money.

(b) Do you mind opening the door?

(c) If you will/would fill in this form, I will just go to the next question.

(d) I would appreciate if you would be so kind as to send me some money.

(e) Would you mind sending me some money?

(f) Would it be a problem if we opened the door?

On the other hand, I randomly sampled one of the above formulae, i.e. (5e), and included it in the elicitation test (see Appendix 1) to double-check the unpopularity of such formulae in Ugandan English. The formula in (5e) always came last among all the alternatives chosen by the respondents, and the most common reason given for its relative rejection is that it makes the request less serious, a position that aligns with Meierkord (2016a: 245), who observed that indirect strategies in Ugandan English are "held to imply that the request is not urgent." The preferred alternatives were mood deliverables and explicit performatives (see below).

An important fact that we should bear in mind is that the L1 expressions in (5) have an idiomatic interpretation, thereby making them requests and not simple interrogative/declarative constructions that are interpretable from a literal perspective. The fact that L2 speakers of English usually tend to disregard the holistic nature of idiomatic expressions (Karlson 2013) makes the above expressions less frequent in Ugandan English. In relation to (5c), many Ugandans even regard it to be ungrammatical. Question 4 of the elicitation test (Appendix 1) sought to find out how Ugandans judge (5c), as preliminary observations had pointed to the rejection of the formula on the basis of its grammaticality. 33 out of the 40 participants $(82.5 \%)$ judged it to be ungrammatical, while $7(17.5 \%)$ said it was grammatical but could not explain its grammaticality. The perceived ungrammaticality in (5c) could be attributed to the fact that grammar books used in the country (e.g. Bukenya, Njeng'ere and Kioko 2015, Kioko and Muthwii 2010) usually insist on the so-called $i f_{1}, i f_{2}$ and $i f_{3}$ (more appropriately known as 
conditional $_{1}$, conditional ${ }_{2}$ and conditional $_{3}$ ), in which the protases (the clauses that express the condition) have invariably the present simple $\left(i f_{1}\right)$, past simple $\left(i f_{2}\right)$ and past perfect $\left(i f_{3}\right)$. In other words, $i$-clauses that do not encode condition (as in (5c) above) are not emphasized in Uganda. Since the protasis in (5c) has will and would + bare infinitive, which are the forms used in the apodosis (the clause that expresses the consequence) for $i f_{1}$ and $i f_{2}$, respectively, the construction is thus judged by many Ugandans as ungrammatical. Ugandans have been reported as speakers of L2 English who can afford to reject some L1 English forms. For example, Isingoma (2014, 2016a) reports that the L1 English expression break up 'close school for holiday', and the L1 English form Pour me some tea are not acceptable in Ugandan English and are replaced by break off and Pour for me some tea, respectively, since they are perceived as ungrammatical or incorrect. Note that in the context of Uganda' s school settings, the terms 'ungrammatical', 'incorrect' and 'unacceptable' are used interchangeably, as English is mainly acquired in school contexts, where such prescriptivism terms have gained a lot of currency. However, despite the prescriptive practices in the country, which are aligned along British English norms, substrate influence and other L2 acquisition processes make Ugandans deviate from these norms insofar as rejecting some British English forms and perhaps even tending towards endonormativity in keeping with Schneider's (2007) model (see also Meierkord 2020).

While the formulae in (5) above are absent in the Ugandan data, there are some occurrences of modal verbs in Ugandan English, as shown in the following table:

\begin{tabular}{|l|l|l|}
\hline Modal phrase & Spoken data & ICE-UG \\
\hline Can you & 07 & 03 \\
\hline Could you & 07 & 00 \\
\hline Would you & 04 & 01 \\
\hline
\end{tabular}

Table 2. Modal verbs used in requests in Ugandan English

The following (in (6)) are examples from the spoken data:

\section{(6) (a) Would}

UGANDAN ENGLISH

(i) Would you help me explain...

(ii) Would you tell us about yourself more...

(iii) Would you like to also tell me...

(b) Can

(i) Can you tell us just briefly...

(ii) So can you explain the different tribes to...

(iii) Can you explain to me what these...

(c) Could

(i) Could you introduce yourselves...

(ii) Could you please say something about...

(iii) Could you tell me what that contains... 
One important observation about the above occurrences is that the 18 cases in the spoken data are all utterances from the interviewers, who were lecturers, while the interviewees were students, middle-level professionals and small scale businesspeople. Lecturers in Uganda are usually the crème de la crème in academic circles and are (or seen to be) highly educated (cf. Kyaligonza and Kamagara 2017). This state of affairs has two implications: (i) it seems to align itself with Meierkord's (2016a) observation as regards the role of exonormativity in the country, since highly educated people would want to maintain what they may perceive as high standards of English in the country, which, given the entrenched exonormative orientation, will approximate L1 standards. (ii) It also seems that given the high status and prestige enjoyed by lecturers in the country, they may regard themselves as people who are permitted to use 'less polite' formulae, which, in the Ugandan context, are actually what L1 speakers regard as highly polite formulae. Recall that according to Lwanga-Lumu (1999) and Blum-Kulka (1987), indirectness may not be seen as a polite strategy in some communities. From the foregoing, it might be right to conjecture that the sporadic use of modal verbs in the interrogative form to express the speech act of request only manifests itself in Ugandan English mainly in top-down communication. The above can be linked to Buregeya's (2004: 109) revelation in Kenyan English, where, out of his 28 students who would write to him making requests, only 1 student used a modal verb in the interrogative form. It thus seems that, in Uganda (and other African countries), someone who is a subordinate (or considers themselves to be one) will as much as possible avoid indirect strategies during acts of bottom-up communication in English. Variational pragmatics (cf. Barron 2014) predicts this kind of scenario, as it underscores the role of micro-social variables with respect to interlocutor status in determining the choice of formulae to use in an act of communication.

The elicitation test (cf. Appendix 1) also sought to examine three mitigators used with mood derivables and explicit performatives in Ugandan English. We are already aware that the two direct strategies are prevalent in Ugandan English and are not regarded as inappropriate, as reported by Meierkord (2016a). However, Meierkord (2016a) only discussed the use of performative verbs without highlighting the mitigators used to make explicit performatives more polite, save for the mitigator please, also discussed by Lwanga-Lumu (2002). One such mitigator is the use of the performative verbs in the past progressive, as shown in (7). I included (7a) in the elicitation test (Appendix 1) in order to mirror what I had routinely observed in both oral and written discourse among Ugandans, as attested in (7b), which I extracted from a presentation in the Parliament of Uganda that was published in a local daily called The Daily Monitor. If one reads the story from which $(7 b)$ is extracted, one will realize that the time of the utterance is co-extensive with the time of making the request.

(7) (a) I was requesting that I bring the results next time. UGANDAN ENGLISH

(b) I was requesting to allow me submit this tomorrow. UGANDAN ENGLISH

(The Daily Monitor 20/02/2017) 


\section{Bebwa Isingoma}

Out of 40 participants, $20(50 \%)$ chose (7a), i.e. with the past progressive, while $12(30 \%)$ chose the form which had the same words as those in (7a) but differed from it in terms of tense; that is, it had the present progressive (I am requesting...). The remainder (i.e. 08 participants $=20 \%$ ) selected the only indirect strategy construction (i.e. Would you mind if I brought the results next time?). ${ }^{3}$ The participants were asked to give reasons for their choices and for not choosing the other alternatives. Expectedly, the 20 participants who selected the form with the past progressive stated that it was more polite than the rest, while those who selected the form with the present progressive argued that the request was being made contemporaneously with the time of speaking, thereby necessitating them to use the present tense. The latter group, thus, argued that the past progressive was ungrammatical. While the past tense can be used in L1 English to make requests more polite, this is restricted to the following verbs: want, need, wonder, think and hope (Carter, McCarthy, Mark and O'Keeffe 2011: 388). In Ugandan English, on the other hand, even verbs or verb phrases such as suggest and be of the view/opinion can be used in the past progressive in order to make suggestions more polite. Thus, although one may argue that leveling is responsible for the use of the past progressive in (7) above (on a par with the L1 English use of the past tense with the five verbs above), it is important to note that substrate influence could be responsible, since in many Ugandan languages, the past tense is used for this purpose, as shown in the Rutooro and Acholi examples in (8) and (9) respectively, which depict a more polite way of saying (3) in Rutooro and (4) in Acholi (see Section 2), where the present progressive is used:

(8) Mbaire ninkusaba ontwekere sente.

M-baire ni-n-ku-sab-a o-n-twek-er-e sente

I-was PROG-I-you-request-FV you-me-send-APPL-FV money

'I was requesting you to send me money.'

(9) Onongo atye kalegi ni icwala cente.

Onongo a-tye ka-leg-i ni i-cwal-a cente

PAST I-am PROG-request-you so that you-send-me money

'I was requesting you to send me money.'

Hence, the form of the verb in (7) could be said to be based on the form of the verb in (8) and (9), a phenomenon that is prevalent in Ugandan Bantu languages (cf. (8)) as well as non-Bantu languages (cf. (9)).

Research into African Englishes (e.g. Lwanga-Lumu 2002, Anderson 2009) has shown that the use of mitigators such as please makes imperatives be seen as a polite strategy for making requests in these L2 varieties of English. Conversely, Swan (2005: 409) argues that the use of please does not turn imperatives into (polite) requests in L1 English (it only turns them into polite orders or instructions). However, some sources indicate that once imperatives are used with mitigators, they acquire an illocutionary force of a request (Quirk et al. 1985: 832, Carter et al. 2011: 127). Another mitigator that is used with imperatives in Ugandan English in order to make humble requests is the word first. Nassenstein (2016: 405) 
shows that L1 English would use 'please' or modals in lieu of Ugandan English first, as shown in (10):

(10) (a) First get me the chair.

$\rightarrow$ UGANDAN ENGLISH

(b) Would you mind getting me the chair? $\rightarrow$ L1 ENGLISH

(c) Please, get me the chair.

$\rightarrow$ L1 ENGLISH

Nassenstein (2016) presented (10a) as a grammatical peculiarity with pragmatic import in Ugandan English, without considering circumstances under which it is used. In order to find out these circumstances, I asked my respondents in the elicitation test (Appendix 1) to select the most appropriate formula, in (10) above, they would use to request someone to pass them a chair in a meeting room, and to give reasons for their choices and why they did not choose the other alternatives. The results are presented in Table 3:

\begin{tabular}{|l|l|l|}
\hline Statement & Frequency & Percentage \\
\hline$(10 \mathrm{a})$ & 12 & $30 \%$ \\
\hline$(10 \mathrm{~b})$ & 08 & $20 \%$ \\
\hline$(10 \mathrm{c})$ & 20 & $50 \%$ \\
\hline
\end{tabular}

Table 3. Results for Question 3 of the elicitation test

While the majority chose (10c), (10a), which has the mitigator first, came second and the L1 preferred version in (10b) came last. Among the several reasons provided for their choices, politeness was cited substantially. But most strikingly was the reason why some respondents did not choose (10a), which was said to only be appropriate if the requestee is socially close to the requester. If this is considered as a representative view, then it brings into play the micro-social parameters advanced in variational pragmatics (Barron 2014) as important variables that determine the form that a speaker adopts in a given speech act. Remarkably, the use of first in (10a) is a calque from indigenous languages. However, contrary to what Nassenstein (2016: 405) claims that this usage is "borrowed from the theoretical frame of Luganda politeness", the fact is that many Ugandan languages (Luganda inclusive) have that form. For example, (10a) is realized in Rutooro, Luganda and Acholi as shown in (11):

(11) (a) Banza ompe entebe Banza o-m-p-e First you-me-give-FV

'First, give/get me the chair.'

(b) Soka ompe entebe

Soka

o-m-p-e

First you-me-give-FV

'First, give/get me the chair.' $\rightarrow$ RUTOORO (BANTU)

entebe.

chair.

$\rightarrow$ LUGANDA (BANTU)

entebe.

chair. 
(c) Kong imi na kom.

$\begin{array}{ll}\text { Kong } \quad \text { i-mi } & \text { na } \\ \text { First } \quad \text { you-give } & \text { me } \\ \text { 'First, give/get me the chair.' } & \end{array}$

$\rightarrow$ ACHOLI (NILOTIC)

kom.

chair

The removal of banza, soka or kong 'first' would make the statement an order/ instruction in the three languages. Ugandan indigenous languages (and not only Luganda, as Nassenstein 2016 reports) are also responsible for the use of imperatives in Ugandan English as polite forms of making requests without being accompanied by overt mitigators, provided the imperatives contain the lexical verb help (cf. Nassenstein 2016: 405) or assist, as shown in (12). Substrate influence can be seen, for example, in the Acholi version of (12) as shown in (13):

(12) (a) Help me with the water.

$\rightarrow$ UGANDAN ENGLISH

(b) Assist me with the water.

$\rightarrow$ ACHOLI (NILOTIC)

(13) Konya ki pii.

Kony-a ki pii

Help-me with water

Lit. 'Help me with water.'

'Would you mind giving me water?'

While Nassenstein (2016: 405) renders (12a) as "Give me the water (if you can)!", for a Ugandan speaker of English, (12a) is the equivalent of Would you mind giving me the water? It is not a simple imperative in the sense of Swan (2005: 411); rather, it is a polite request. In this context, the verbs help and assist intrinsically contain mitigating semantics. Again, in order to find out to what extent the formula in (12a) is accepted and used in Ugandan English, I asked my respondents to choose between (i) Help me with water and (ii) Would you mind giving me water? (Appendix 1). They were asked to choose the construction they would use if they were thirsty and were looking for water to drink. Out of the 40 participants, 32 chose (i), while 08 chose (ii). The respondents were also asked to give reasons why they would prefer to use either of the two constructions. They gave several reasons, but prominent among them was politeness. 25 of the 32 who chose (i) said that it was a polite way of requesting something, while 6 of the 8 who chose (ii) also said that (ii) was a polite way of making a request. One important observation can be made here: although (ii) is not very popular among Ugandans, as also evidenced in the responses with respect to two of the other questions in the elicitation test (cf. Appendix 1) already discussed above, it is not alien to them, because grammar books used in Ugandan schools emphasize the use of such expressions. For example, a popular book by Bamwoyeraki, Nakangu and Ocwinyo (2010: 101-2) emphasizes the use of the following constructions as polite ways of making requests: Would you dance with me?, Would you open the window?, Do you mind if I close the door?, Would you mind if I closed the door?, Would you mind closing the door? However, substrate influence is so strong that many speakers prefer calqued expressions and forms from indig- 
enous languages, which they feel are more appropriate than the exonormative forms dictated by schools and textbooks.

Lastly, from the perspective of postcolonial pragmatics (Anchimbe and Janney 2011), cases of the direct strategy discussed above (because of explicit performatives and imperatives) should not be regarded as being inappropriate, because for speakers of this postcolonial English, explicit performatives and imperatives with appropriate mitigators make the statements not only plain requests, but polite ones. Thus, contrary to Swan (2005: 411), who looks at the mitigator please as a device that cannot change imperatives into requests, postcolonial pragmatics, which recognizes the hybridic nature of discourse in a country such as Uganda, would regard devices such as first, please, the past progressive used with performative verbs, as well as the verbs help and assist, which have inherent supplicatory semantics used in imperatives, as devices that indeed make statements in which they are used become legitimate polite requests in a postcolonial community of practice.

\subsection{Responses to thanks}

Studies on how people respond to thanks show a lot of variation in responses provided by L1 speakers and L2 speakers of English (cf. Schneider 2005, Ouafeu 2009, Schröder and Schneider 2018). According to Swan (2005: 434), the British usually do not respond to thanks, but when they have to, they use: not at all, you're welcome, that's (quite) all right, that's okay or no problem. In addition to most of the replies listed by Swan (2005), Schneider (2005) includes anytime, my pleasure, don't mention it, don't worry about it, thanks and yeah as responses observable in three L1 Englishes (American, British and Irish English). ${ }^{4}$ Of these, according to Schneider (2005), (you're) welcome is the most used overall.

As pointed out in Section 3, data for this part of the current study was collected by means of a DCT and naturally occurring conversations. The results for the two exercises are shown in the tables below:

\begin{tabular}{|l|l|l|}
\hline Response & Frequency & Percentage \\
\hline (You're) welcome & 30 & 75.0 \\
\hline Thank you (too)/Likewise & 04 & 10.0 \\
\hline Fine & 3 & 7.5 \\
\hline OK & 2 & 5.0 \\
\hline All right & 1 & 2.5 \\
\hline
\end{tabular}

Table 4. Results for the DCT

\begin{tabular}{|l|l|l|}
\hline Response & Frequency & Percentage \\
\hline (You're) welcome & 21 & 52.5 \\
\hline Thank you (too)/thanks (too) & 10 & 25.5 \\
\hline (It's) OK (please) & 4 & 10.0 \\
\hline
\end{tabular}




\begin{tabular}{|l|l|l|}
\hline Response & Frequency & Percentage \\
\hline (It's) all right (please) & 4 & 10.0 \\
\hline Not (that) much/not all that & 2 & 5.0 \\
\hline It's a pleasure/my pleasure & 2 & 5.0 \\
It's fine & 2 & 5.0 \\
No response & 1 & 2.5 \\
\hline
\end{tabular}

Table 5. Results for the naturally occurring data

Read together, the two tables clearly show us that the most common strategy in Ugandan English is expressing appreciation by means of the expression (you're) welcome, thereby making Ugandan English share the prevalence (albeit at varying degrees) in usage with L1 English (cf. Schneider 2005, Aijmer 1996). However, if the trend observed by Dikin (2017) as regards the decline in the use of (you're) welcome in Canadian English in preference to no problem (especially among the young generation) is also present in other L1 Englishes, then the use of (you're) welcome may remain only more prevalent in L2 Englishes such as Ugandan English. As a formal expression in British English (Aijmer 1996, Schneider 2005: 129), this is the response that is taught in Ugandan schools as a polite formula that one is supposed to use. As Meierkord (2016a: 244) notes, English in Uganda is acquired "through formal instruction along the lines of formal British English." Farenkia (2013) has noted that expressing appreciation (using (you're) welcome) is also the mostly used strategy in Cameroon English (also an L2 variety), although a study by Ouafeu (2009) indicates that the mostly used strategy in Cameroon English is acknowledging the thanks by means of the expression yes.

The second most striking strategy in the two tables above is returning the thanks. It is a significant strategy in two ways: first, there is a discrepancy between the results obtained by means of the DCT (Table 4) and the results from the naturally occurring data (Table 5). That is, while the DCT results indicate $10 \%$ of the respondents used this strategy, the results from naturally occurring data give us 25\%. This is, however, not surprising, as the DCT gave the respondents time to think about (possibly) what they were taught in school, i.e. the option of having recourse to some metalingual reflection, where the use of (you're) welcome comes to the fore, and this depicts the scenario of varied results we observe in Ouafeu's (2009) study, who used naturalistic data, in which yes was the most prevalent response in Cameroon English, while Farenkia (2013), who used DCTs, came up with welcome (and its variants) as the most used response in the same variety of English. In a similar vein, Kasanga (2006) observes that there was a tendency by speakers of Black South African English to produce more L1-like formulae in the DCT data than those they produced in naturalistic and observational situations (although here the topic was about making requests). Thus, the discrepancy above reechoes the observation made by Schneider (2005) and reiterated by Bieswanger (2015) as regards the need to triangulate DCTs with other tools. The second aspect of the significance of the use of the strategy of returning the thanks is that Ugandan English sharply diverges from L1 English with respect to the frequency of usage of reciprocated thanks, which only occurs 
in L1 English very peripherally and only under certain circumstances (cf. Schneider 2005). Note that the response thank you too (and its variants) is not taught in schools as a response to thanks, but comes in the main from substrate influence (see Section 2). While reciprocated thanks occurs in Ugandan English as a result of the thanker having also done something for the thankee, as is the case in L1 English (cf. Schneider 2005), it also occurs as a way of showing gratitude to the thanker for having thanked the thankee, since, for example, in Rutooro, it is also possible to say Naiwe webale kusiima 'thank you too for thanking me' as a response to thanks. Moreover, the fact that reciprocated thanks was used in the DCT (even though with a lower incidence of occurrence), where the discourse situation did not involve the thanker having done something for the thankee, may be indicative of a situation where the respondents simply thought of thanking the thanker for having thanked them. It thus seems that, usually, Ugandans invoke the dichotomy 'surface-level expressions/phrases vs. the pragmatic assessment of their use' in terms of their efficacy in encoding politeness based on local socio-cultural realities and practices. This sometimes triggers the spontaneous use of expressions usually stemming from substrate influence when the interlocutors are involved in naturalistic discourse, as opposed to when the interlocutors are involved in some kind of metalingual reflections, i.e. when they have the leverage to have recourse to exonormative rules taught at school (see also Meierkord 2020).

Another response that comes from substrate influence, albeit with a low incidence of occurrence, is not (that) much/not all that, realized in Luganda, Rutooro and Acholi as si nnyo, tikuli muno and pee tutwal, respectively. This expression of minimizing the favor has not been reported in other L2 varieties of English hitherto studied. Crucially, this response did not occur in the DCT, again, possibly due to the fact that, here, the responses were not as naturalistic as they were in the naturally occurring data. One other advantage of using the naturally occurring data is that it has enabled us to have an option of 'no response' (albeit with a very low rating), which we could not have in the DCT, since here one was required to write something (see also Bieswanger 2015: 537, who was able to observe non-verbal acknowledgments of thanks in naturalistic data, though this is different from 'no response'). However, in line with Schneider's (2005) and Kasanga's (2006) observations, the DCT has provided us with an opportunity to assess what the respondents think they should say, while depicting the picture of what they think other Ugandans should say.

As can be noticed in Table 5, Ugandan English $O K$ may be accompanied by please - a direct translation from bambi found in Luganda, Lusoga and other Bantu languages, where kale bambi 'OK please' is commonly used. A similar expression aya baa 'OK please' is used in Acholi and Lango (Nilotic languages). ${ }^{5}$ Isingoma (2016b: 167) explains that adding please to $O K$ portrays a positive attitude of the speaker; whence, it makes the response more polite. The use of please in situations where speakers of L1 English would not use it has also been reported in Ghanaian English, where constructions such as Please, thank you; Please, good evening; Please, you are stupid are said to occur (Anderson 2009: 75-6). Thus, while Ugandan English shares with Ghanaian English the property of the extended use of the mitigator please, the extent of the actual use is different. 


\section{Bebwa Isingoma}

Clearly, there are several formulae that are used in L1 English but do not occur in the Uganda data, notably no problem, anytime, don't mention it, don't worry about it and not at all, although anecdotally I have heard the latter among Ugandans. According to Swan (2005: 434), the expression not at all is "rather formal", and this may explain why it sometimes occurs in Ugandan English. Expectedly, the absence of no problem, anytime and others in the Uganda data may be accounted for by the fact that they are informal formulae in L1 English (cf. Swan 2005, Schneider 2005) and, as aforementioned, Ugandan English is mainly based on formal British English. Not surprisingly, however, these expressions occur in Namibian English, an African L2 variety of English, and this could be accounted for by the fact that Namibian English is historically linked to South African Englishes (cf. Schröder and Schneider 2018), which have a comparatively high level of L1 English informal expressions as opposed to Ugandan English, because of the settler population effects. That is, since Uganda was not a settler colony, there were very few L1 English settler communities to facilitate the acquisition of English in informal settings (Meierkord 2016c).

\section{Conclusion}

As research into Ugandan English continues to take shape following recent awakenings, many of its features have been brought to the limelight. This study has added insights into the few cases in which the pragmatic and discoursal idiosyncrasies of Ugandan English have been addressed. As is expected, some features are shared with other L2 varieties of English mainly due to similar underlying cultural and linguistic conceptualizations, while others are unique to Ugandan English. As Anchimbe (2019) argues, a fuller appreciation of the features of postcolonial Englishes is effortlessly realized through the lenses of frameworks such as postcolonial pragmatics and the World Englishes Paradigm, where peculiarities of the sort are positively identified in their own right. Thus, for example, while imperatives cannot be used to encode an illocutionary act of a (polite) request in L1 English (cf. Swan 2005), in Ugandan English, they can, as long as they are used with mitigators.

Since the forms hitherto used by Ugandans have effectively served their communicative purposes, there seems to be no need, on the national level, to emphasize British or American English forms in Uganda, some of which are even construed by Ugandans as not polite enough or even ungrammatical. Crucially, what we have seen in the study shows the functionality of Ugandan English as a resourceful tool for maintaining indigenous sociolinguistic norms despite the ubiquitous use of English, which naturally comes with its own conventions. The hybridic nature of the formulae used in Ugandan English aggregates, in an idiosyncratic way, what speakers of English in Uganda have deemed fit in the English language and what they see as something that cannot be abandoned from their indigenous languages.

Given that Ugandans can afford to reject some British English forms as incorrect (for example, (5c), i.e. If you will/would fill in this form, I will just go to the next 
question) and given that, contrary to British English norms, directness in making requests is not seen as inappropriate or impolite in Ugandan English, we are clearly witnessing the nativization of English in Uganda in the sense of Schneider (2003, 2007). But more importantly, that seems to point to aspects of endonormative orientation as well, which has the key element of the gradual development of a positive attitude towards the features of the local variety, despite the fact that there might be resistance to these features by some sections of the population (who still espouse exonormativity). Thus, while Ugandan English has no doubt reached the nativisation phase (Isingoma and Meierkord 2019), some indicators of endonormativity are visible, despite the dictates of the historical exonormative orientation. It thus seems right to support the idea that there are intersectional elements that straddle Schneider's $(2003$, 2007) model at the transitory level from nativisation to endonormative stabilization, where some aspects of endonormativity are already visible in the nativization phase, parallel to how some aspects of nativisation are visible right in the phase of exonormative stabilization, as Schneider $(2003,2007)$ himself points out.

\section{Notes}

$1 \quad$ CCSARP $=$ Cross-Cultural Speech Act Realization Patterns

2 Abbreviations and notation in the interlinear glosses in this study: APPL= Applicative; FV= Final Vowel; PRES= Present; PROG= Progressive.

3 I will not discuss this form here, as I have already discussed its situation while looking at indirect strategy formulae above.

4 For British English, Schneider (2005) only looked at English as spoken in England.

$5 \quad$ See also Lwanga-Lumu (2002) for the idiosyncratic use of please in making requests among L1 Luganda speakers of English in Uganda.

\section{References}

Aijmer, Karin (1996) Conversational Routines in English: Convention and Creativities. London: Longman.

Anchimbe, A. Eric and Richard W. Janney (2011) Postcolonial pragmatics, Journal of Pragmatics 43, 145-159.

Anchimbe, A. Eric (2019) Offers and Offer Refusals: A Postcolonial Pragmatics Perspective on World Englishes. Amsterdam: John Benjamins.

Anderson, A. Jemima (2009) Polite requests in non-native varieties of English: The case of Ghanaian English. Linguistica Atlantica 30, 50-86.

Anthony, Laurence (2004) AntConc: A learner and classroom friendly, multi-platform corpus analysis toolkit. Proceedings of IWLeL, 7-13.

Bamwoyeraki, Sophie, Edith Nakangu and Julius Ocwinyo (2010) Fountain Progressive English for Secondary Schools. Kampala: Fountain Publishers.

Barron, Anne (2014) Variational pragmatics. In: Chapelle, A. Carol (ed.) The Encyclopedia of Applied Linguistics. New Jersey: Blackwell Publishing, 1-7.

Barron, Anne and P. Klaus Schneider (2009) Variational pragmatics: Studying the impact of social factors on language use in interaction. Intercultural Pragmatics 6 (4), 425-442. 


\section{Bebwa Isingoma}

Bieswanger, Markus (2015) Variational pragmatics and responding to thanks - revisited. Multilingua 34 (4), 527-546.

Blum-Kulka, Shoshana (1987) Indirectness and politeness in requests: same or different? Journal of Pragmatics 11, 131-146.

Blum-Kulka, Shoshana and Elite Olshtain (1984) Requests and apologies: A cross-cultural study of speech act realization patterns (CCSARP). Applied Linguistics 5(3), 196-213.

Blum-Kulka, Shoshana, Juliane House and Gahriele Kasper (1989) Cross-cultural Pragmatics: Requests and Apologies. Berlin: Mouton de Gruyter.

Brown, Penelope and Stephen Levinson (1978) Universals in language usage: Politeness phenomena. In: Esther N. Goody (ed.), Questions and Politeness. Cambridge: Cambridge University Press, 56-311.

Brown, Penelope and Stephen Levinson (1987) Politeness: Some Universals in Language Usage. Cambridge: Cambridge University Press.

Bukenya, Austin, David Njeng'ere and Angelina Kioko (2015) Head Start Secondary English: Book Three. Nairobi: Oxford University Press East Africa Ltd.

Buregeya, Alfred (2004) Written requests in Kenyan English: An illustration of L1 culture adaptation in L2 acquisition. Occasional Papers in Language and Linguistics 2, 103-123.

Carter, Ronald, Michael McCarthy, Geraldine Mark and Anne O'Keeffe (2011) English Grammar Today. Cambridge: Cambridge University Press.

Dikin, J. Aaron (2017) It's no problem to be polite: Apparent-time change in responses to thanks. University of Pennsylvania Working Papers in Linguistics 23 (2) 2019, 58-67.

Eberhard, M. David, Gary F. Simons and Charles D. Fennig (eds.) (2015) Ethnologue: Languages of the World, 18th ed. Dallas, TX: SIL International.

Farenkia, Mulo Bernard (2013) "All thanks goes to the Almighty" - A variational and postcolonial pragmatic perspective on responses to thanks. Sino-US English Teaching 10 (9), 707-724.

Fisher, E. C. Allestree (2000) Assessing the State of Ugandan English. English Today 16 (1), $57-61$.

Goffman, Erving (1967) Interaction Ritual: Essays on Face-to-face Behavior. Garden City, NY: Anchor.

Gough, H. David (1995) Some problems for politeness theory: deference and directness in Xhosa performative requests. South African Journal of African Languages 15, 123-5.

Greenbaum, Sidney and Gerald Nelson (1996) The international corpus of English (ICE) project. World Englishes 15 (1), 3-15.

Isingoma, Bebwa (2013) Innovative pragmatic codes in Ugandan English: A relevance-theoretic account. Argumentum 9, 19-31.

Isingoma, Bebwa (2014) Lexical and grammatical features of Ugandan English. English Today 30 (2), 51-56.

Isingoma, Bebwa (2016a) Lexical borrowings and calques in Ugandan English. In Christiane Meierkord, Bebwa Isingoma and Saudah Namyalo (eds.), Ugandan English: Its Sociolinguistics, Structure and Uses in a Globalizing Post-protectorate. Amsterdam: John Benjamins, 149-172.

Isingoma, Bebwa (2016b) The use of ditransitive constructions in Ugandan English. In: Christiane Meierkord, Bebwa Isingoma and Saudah Namyalo (eds.) Ugandan English: Its Sociolinguistics, Structure and Uses in a Globalizing Post-protectorate. Amsterdam: John Benjamins, 201-226.

Isingoma, Bebwa and Christiane Meierkord (2019) Capturing the Lexicon of Ugandan English: ICE-Uganda and its Effective Complements. In: Alexandra U. Esimaje, Ulrike. Gut and Bassey E. Antia (eds.) Corpus Linguistics and African Englishes [Studies in Corpus Linguistics 88]. Amsterdam: Benjamins, 294-328.

Karlson, Monica (2013) Quantitative and qualitative aspects of L1 (Swedish) and L2 (English) idiom comprehension. Studies in Second Language Learning and Teaching 3 (2), 293-319. 
Kamoga, Katabazi Frederickand Earl W. Stevick (1968) Luganda: Basic Course. Washington: Foreign Service Institute.

Kasanga, A. Luanga (2006) Requests in a South African variety of English. World Englishes 25(1), 65-89.

Kioko, Angelina and Margaret J. Muthwii (2010) Spot on Grammar for Secondary Schools. Nairobi: Oxford University Press East Africa Ltd.

Kyaligonza, Robert and Edson Kamagara (2017) Staff turnover in public universities in Uganda. Makerere Journal of Higher Education 9 (2), 59-72.

Lwanga-Lumu, C. Joy (1999) Politeness and indirectness revisited. South African Journal of African Languages 19 (2), 83-92.

Lwanga-Lumu, C. Joy (2000) Requests and apologies in Luganda and English. PhD dissertation. University of the Witwatersrand, Johannesburg.

Lwanga-Lumu, C. Joy (2002) Internal request modification by first and second language speakers. Journal of Language Teaching/Tydsrif vir Taalonderring 36 (3-4), 289-304.

Meierkord, Christiane (2016a) Speech acts in Ugandan English social letters: Investigating the influence of sociocultural context. In: Christiane Meierkord, Bebwa Isingoma and Saudah Namyalo (eds.) Ugandan English: Its Sociolinguistics, Structure and Uses in a Globalizing Post-protectorate. Amsterdam: John Benjamins, 227-248.

Meierkord, Christiane (2016b) Diphthongs in Ugandan English: Evidence for and against variety status and Interactions across Englishes. In: Christiane Meierkord, Bebwa Isingoma and Saudah Namyalo (eds.) Ugandan English: Its Sociolinguistics, Structure and Uses in a Globalizing Post-protectorate. Amsterdam: John Benjamins, 121-147.

Meierkord, Christiane (2016c) A social history of English(es) in Uganda. In Christiane Meierkord, Bebwa Isingoma and Saudah Namyalo (eds.) Ugandan English: Its Sociolinguistics, Structure and Uses in a Globalizing Post-protectorate. Amsterdam: John Benjamins, 51-71.

Meierkord, Christiane (2020) Attitudes towards exogenous and endogenous uses of English: Uganda's judgements of English structures in varieties of English. International Journal of English Linguistics 10 (1), 1-14.

Namyalo, Saudah, Bebwa Isingoma and Christiane Meierkord (2016) Towards assessing the space of English in Uganda's linguistic ecology: Facts and issues. In: Christiane Meierkord, Bebwa Isingoma and Saudah Namyalo (eds.) Ugandan English: Its Sociolinguistics, Structure and Uses in a Globalizing Post-protectorate. Amsterdam: John Benjamins, 19-49.

Nassenstein, Nico (2016) A preliminary description of Ugandan English. World Englishes 35 (3), 396-420.

Ouafeu, T. S. Yves (2009) Thanking responders in Cameroon English. World Englishes 28 (4), 544-551.

Quirk, Randolph, Sidney Greenbaum Geoffrey Leech and Jan Svartvik (1985) A Comprehensive Grammar of the English Language. London: Longman.

Schneider, P. Klaus (2005) No problem, you're welcome, anytime: Responding to thanks in Ireland, England, and the USA. In: Anne Barron and Klaus P. Schneider (eds.) The Pragmatics of Irish English. Berlin: Mouton de Gruyter, 99-139.

Schröder, Anne and Klaus P. Schneider (2018) Variational pragmatics, responses to thanks, and the specificity of English in Namibia. English World-Wide 39(3), 338-363.

Ssempuuma, Jude, Bebwa Isingoma and Christiane Meierkord (2016) The Use of the progressive in Ugandan English. In Christiane Meierkord, Bebwa Isingoma and Saudah Namyalo (eds.) Ugandan English: Its Sociolinguistics, Structure and Uses in a Globalizing Post-protectorate. Amsterdam: John Benjamins, 173-199.

Swan, Michael (2005) Practical English Usage. Oxford: Oxford University Press.

The Daily Monitor. https://www.monitor.co.ug/Magazines/PeoplePower/Ruhindi-to-MPs-I-did-not-do-anything-extraordinary/689844-3817940-pnb6oqz/index.html (accessed on 19/06/19). 


\section{Bebwa Isingoma}

The International Corpus of English - Uganda (ICE-UG): https:/ / www.rub.de/englin/research UG3.html (accessed on 17/06/19).

\section{Appendix 1: Elicitation test}

1. You are thirsty and are looking for water to drink. You see someone who has drinking water. Select the construction you would use to request water from this person (after greeting him/her). Give reasons for your choice and for not choosing the other construction:

(a) Would you mind giving me water?

(b) Help me with water.

2. You have gone to visit your parents with whom you always speak English. When talking to them, you realize that you forgot to bring your Semester 1 results. Select the most appropriate way of requesting your parents to allow you to bring the results next time. Give reasons for your choice and for not selecting the other alternatives:

(a) I am requesting that I bring the results next time.

(b) I was requesting that I bring the results next time.

(c) Would you mind if I brought the results next time?

3. You are supposed to attend a meeting and enter the meeting room but cannot reach the only free chair and you would like someone near it to pass it to you. Select the most appropriate alternative below you would use in order to make your request. Give reasons for your choice and for not selecting the other alternatives:

(a) First get me that chair.

(b) Would you mind getting me that chair?

(c) Please, get me that chair.

4. State whether the following statement is grammatical or not. Give reasons for your answer.

(a) If you will/would fill in this form, I will just go to the next question.

\section{Appendix 2: Discourse Completion Task}

1. In the following conversation, someone has lost his way and asks you to give him/her the right directions. After you have given him/her the directions, he/ she thanks you, by saying 'thank you'. Write down in the blank space below your response to his/her expression of gratitude.

Someone: Hello, I'm lost.

You: Where're you going?

Someone: I'm going to Mr. Opio's home. He lives in this village. 
You: $\quad$ Oh, I know his place. Just continue straight and count five homesteads. The sixth is his.

Someone: Great! Thank you!

You:

Bebwa Isingoma holds a PhD in English Linguistics (University of Agder, Norway) and is currently a senior lecturer in English Language and Linguistics at Gulu University (Uganda), where he also serves as the Dean, Faculty of Education and Humanities. He is an African Humanities Program fellow (2014-15) with a residency at Rhodes University (South Africa) and a European Union Marie S. Curie fellow (2018-19) with a residency at the Freiburg Institute for Advanced Studies (University of Freiburg, Germany). He publishes in areas of variational sociolinguistics, pragmatics and syntax.

Address: Bebwa Isingoma, Faculty of Education and Humanities, Gulu University, P. O. Box 166, Gulu, Uganda. [email: isibebwa@yahoo.co.uk; b.isingoma@gu.ac.ug] 
